\title{
Impact of sewage and industrial pollution on the hydrographic conditions of seawater in Gwadar (East Bay), Balochistan
}

\author{
Rashida Qari*, Khurrum Khalid \\ Institute of Marine Science, University of Karachi, Karachi, Pakistan
}

\begin{abstract}
Hydrographic conditions of seawater play an important role in the marine ecosystem. Today oceans and seas are under tremendous threat and pressures due to increase in man-made activity around the coastal areas like industrialization. To know the impact of these activities on hydrographic conditions (such as colour, temperature, salinity, $\mathrm{pH}$, dissolved oxygen and biological oxygen demand) in surface seawater and deep seawater of Gwadar East Bay was studied during the month of September, 2017. For this samples were taken from six stations, three stations from each of surface seawater and deep seawater. The hydrographic parameters of seawater showed considerable tidal variations. On the basis of data it was concluded that the variations were found between all six stations of both surface seawater and deep seawater. It is also noted that significant correlations were found in between temperature, salinity and dissolve oxygen. Analysis of variance reveals that the results of each parameter were not constant but varied between stations and collection time. The present study is reveal that physic-chemical composition of Gwadar East Bay seawater depends on tidal, depth and discharge of sewage and waste materials from different sources.
\end{abstract}

Citation: Qari R, Khalid K (2018) Impact of sewage and industrial pollution on the hydrographic conditions of seawater in gwadar (east bay), balochistan, GJBAHS 7: 2. doi:

Recieved date: August 21, 2018; Accepted date: August 29, 2018; Published date: September 10, 2018

Copyright: (C) 2018 Qari, et al. This is an open-access article distributed under the terms of the Creative Commons Attribution License, which permits unrestricted use, distribution, and reproduction in any medium, provided the original author and source are credited.

Competing Interests: The authors have declared that no competing interest exist.

Sources of funding: No Funding.

*Email: rqari2002@yahoo.com

\section{Keywords:}

Seawater; Hydrographic conditions; Gwadar East Bay; Colour; Temperature; Salinity; $\mathrm{P}^{\mathrm{H}}$; Dissolved Oxygen; BOD.

\section{Introduction}

Studies on the hydrographic conditions or physicochemical properties of the seawater in different marine areas for various goals are found in the literature. Eswari et al. [1] studied physic-chemical analysis of two different water bodies of Marine Beach Chenna, along the Bay of Bengal whereas Clara Jeyageetha and Kumar [2] described the physico-chemical parameters of seawater in Tuticorin Coastal areas, India. Sekar et al. [3] have studied impact of industrial pollution on the physico-chemical characteristics of seawater in
Thoothukudi coastal area, Gulf of Mannar. Khan et al. [4] surveyed the benthic community of Gwadar East Bay of Balochistan. Saleem and Khan (1999) [5] found high concentrations of heavy metals in the sediment of Gwadar East Bay. Nair and Balchand [6] described the hydrographic properties (temperature, salinity, $\mathrm{pH}$, and dissolved oxygen) in the mud bank area of south west of India. Some hydrographic parameters in a tidal creek opening in the Bay of Bengal (India) reported by Mitra et al. [7]. De Sousa and Singbal [8] studied relationship between nutrients and dissolved oxygen in the central basin of the Arabian Sea. Naqvi et al. [9] worked on a relationship between nutrients and dissolved oxygen with special reference to water masses in the western Bay of Bengal. Gupta et al. [10] studied hydrographic features of the Northern Basin of the Arabian Sea. Ganapati et al. [11] 
studied the vertical distribution of chemical constituents in the shelf waters off Waltair India.

The Gwadar East Bay is situated at $24^{\circ} 07^{\prime} 35^{\prime \prime} \mathrm{N}$ $62^{\circ} 19^{\prime} 21^{\prime \prime} \mathrm{E}$ on the southwestern coast of Arabian Sea, approximately $710 \mathrm{~km}$ West of Karachi. It is still undisturbed area and it is not easily accessible although it is chief port and Fish harbour (covered area: 30 hector) due to lack of investment, security concern etc. The area is highly productive and red tide blooms have been observed in the winter monsoon period (Rabbani et al. [12]. Recently a number of industries have been developed around the Gwadar East Bay for example Gel mineral water plant, Al Makran Ice factory, Mir seafood companies and Desalination plant. At the East Bay of Gwadar boat building and repairing is also continues. At Gwadar China Power Company Head Sho set up for 300 megawatts coal based power plant is ready. The hydrographic studies of the Gwadar coast have not been made at the present stations although some studies related to other areas of Gwadar coast have been made [4,5,12] Hence the present study was undertaken to know the seawater quality of East Bay Gwadar through the analysis of hydrographic conditions of seawater samples collected from different stations for describing the pollution status in this area.

\section{Materials and Methods}

\section{Site}

Gwadar Port is the third port of Pakistan situated on the South Western coast of Balochistan. The city is located on the shores of the Arabian Sea about 710 $\mathrm{km}$ to the West of Pakistan's largest city Karachi. Gwadar is near the border with Iran and is located to the east of the Persian Gulf and opposite Oman. The rocky headland of Gwadar town connected to mainland. The population of Gwadar is over 120,000 . More than $50 \%$ of the population is engaged in fishing activity. The fishermen's boats occupy a very large stretch of the East Bay where fish landing and boat building and repairs take place. About 400 boats (mostly small) are busy in fishing in the territorial waters. Different type of fauna and flora are found such as Gastropods, Bivalves, Arthropod, Echinoderm, Annelids and algae [4]. In Gwadar heavy metal minerals are found in the range of $1-0.15 \%$ (Memon and Ali [13].

\section{Sample Collection}

The samples of seawater were collected in the month of September, 2017 from three stations of East Bay of Gwadar near to mini port, Balochistan (Figure 1). The stations were randomly selected in the surface and depth $(1.5 \mathrm{M})$ at low water mark. Temperature and $\mathrm{pH}$ were noted on sites. Samples for salinity were collected in salinity bottles where as samples for dissolved oxygen and Biological Oxygen Demand (BOD) were taken in respective oxygen bottles $(100 \mathrm{~mL})$.

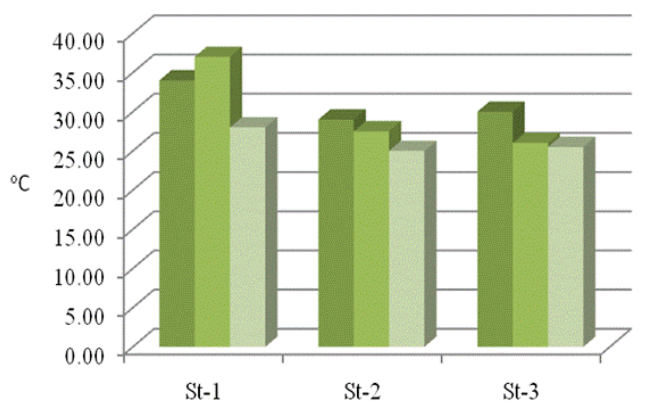

m Air temperature $₫$ Temperature in surface seawater $₫$ Temperature in deep seawater

Figure 1: Variation in temperature of air and seawater at three stations of Gwadar East Bay.

\section{Analysis}

Temperature of air and seawater from all stations of surface and depth were recorded, using mercury thermometer. $\mathrm{pH}$ of seawater samples was measured with the help of $\mathrm{pH}$ paper at the collection time of each sampling. Salinity was measured by the hand-holding Refractometer. Winkler titration method, used for the determination of dissolved oxygen concentration in seawater Martin, [14]. For determination of BOD the direct method of Rodier, [15] and Marr and Cresser, [16] were used.

\section{Result and Discussion}

There was large variation found in the values of hydrographic conditions of seawaters collected from three stations at each surface and deep seawater of Gwadar East Bay. The detail account of hydrographic conditions for all six stations at surface seawater and in deep seawater of Gwadar Bay is given in Figures 2-6. The seawater colour was greenish blue and odour was more or less stinky. Temperature is the physical property which is most easily measured especially sea surface 
temperature by La Fond, [17]. The air temperature was varied from $29^{\circ} \mathrm{C}$ to $34^{\circ} \mathrm{C}$ with the mean value of $31 \pm 2.64^{\circ} \mathrm{C}$ at all three stations of surface seawater of Gwadar East Bay throughout the study period. The temperature of surface seawater ranged from $26-37^{\circ} \mathrm{C}$ with the mean value of $30.17 \pm$ $5.97^{\circ} \mathrm{C}$. The temperature of deep seawater ranged from $25.0^{\circ} \mathrm{C}$ to $28^{\circ} \mathrm{C}$ and the mean was $26.17 \pm$ $1.61^{\circ} \mathrm{C}$. The results of temperature for surface seawater and deep seawater showed that in deep seawater samples, temperature was low as compared to surface seawater (Figure 2).

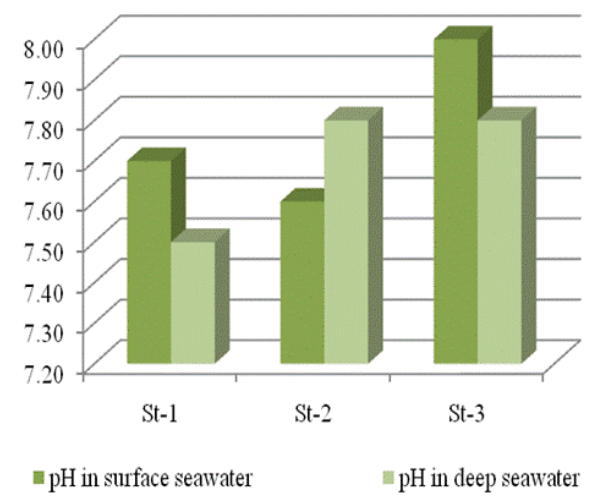

Figure 2: Variation in $\mathrm{pH}$ of seawater at three stations of Gwadar East Bay.

The $\mathrm{pH}$ of surface seawater ranged from 7.6-8 and the mean was $7.8 \pm 2.84$ and in deep seawater $\mathrm{pH}$ range was 7.5-7.8 with the mean value of $7.7 \pm$ 0.17 . An increase was observed in $\mathrm{pH}$ of surface seawater at stations 1 and 3 whereas at station $2 \mathrm{pH}$ of deep seawater was high as compared to surface seawater (Figure 3). The salinity of surface seawater ranges from $39-41 \%$ and the mean was 40 $\pm 1.0 \%$ whereas $37-39 \%$ ranges for deep seawater with mean concentration of $38 \pm 1$ at Gwadar East Bay (Figure 4).

The dissolved oxygen in surface seawater ranged from $1.7-2.84 \mathrm{~mL} \mathrm{~L}^{-1}$ and the mean was $2.27 \pm 0.57$ $\mathrm{mL} \mathrm{L}^{-1}$ whereas for deep seawater the dissolved oxygen range was 2.27-2.84 and the mean was 2.6 $\pm 0.3 \mathrm{~mL} \mathrm{~L}^{-1}$ (Figure 5). In surface water the dissolved oxygen concentration was high as compared to the deep seawater. The BOD of surface seawater of Gwadar East Bay ranged from $0.56-0.62 \mathrm{~mL} \mathrm{~L}^{-1}$ with the mean value of $0.6 \pm 0.03$

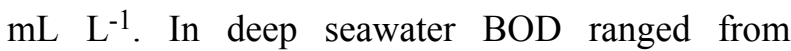
$0.62-0.97 \mathrm{~mL} \mathrm{~L}^{-1}$ with the mean of $0.77 \pm 0.18 \mathrm{~mL}$ $\mathrm{L}^{-1}$ during the study period (Figure 6). At surface seawater BOD value was low as compared to the deep seawater.

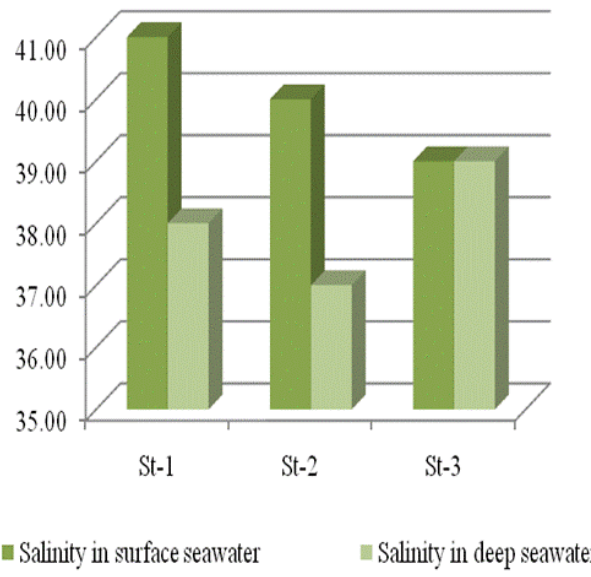

Figure 3: Variation in salinity of seawater at three stations of Gwadar East Bay.

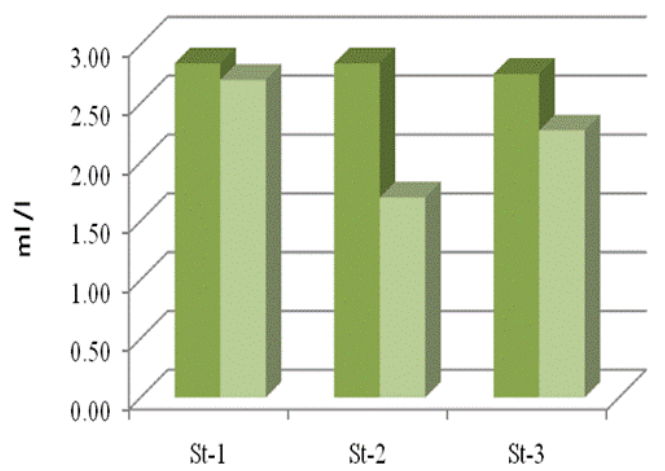

- Dissolved 02 n surface seawater $\quad$ Dissolved 02 in deep seawater

Figure 4: Variation in dissolved oxygen of seawater at three stations of Gwadar East Bay.

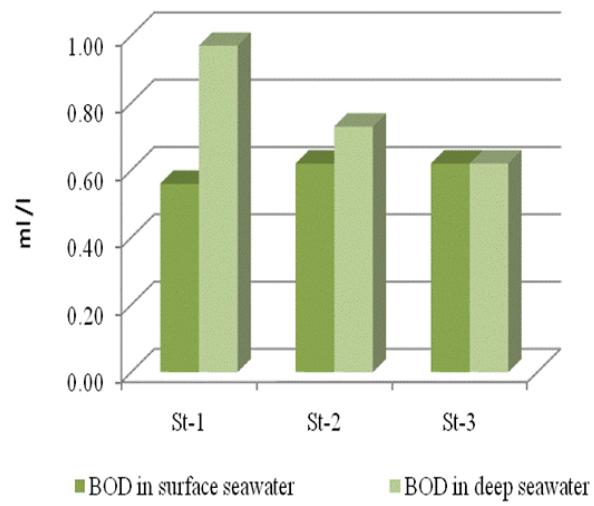

Figure 5: Variation in biochemical oxygen demand of seawater at three stations of Gwadar East Bay. 


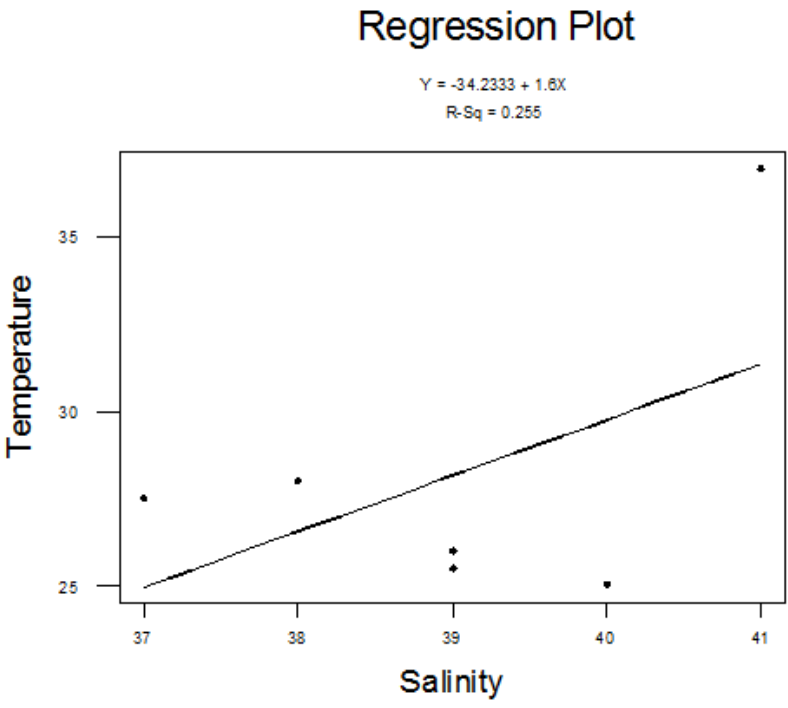

Figure 6: Relationship between temperature and salinity of seawater collected from Gwadar East Bay.

The results of two way Analysis of Variance (ANOVA) in hydrographic condition of seawater from all studied stations of Gwadar East Bay show that there was significant variations observed in salinity in between surface seawater and deep seawater $(p<0.05)$. There was significant correlation observed in between seawater temperature and salinity $\left(\mathrm{r}^{2}=0.505\right)$ and temperature and dissolved oxygen $\left(\mathrm{r}^{2}=0.640\right)$ (Figure 7).

\section{Regression Plot}

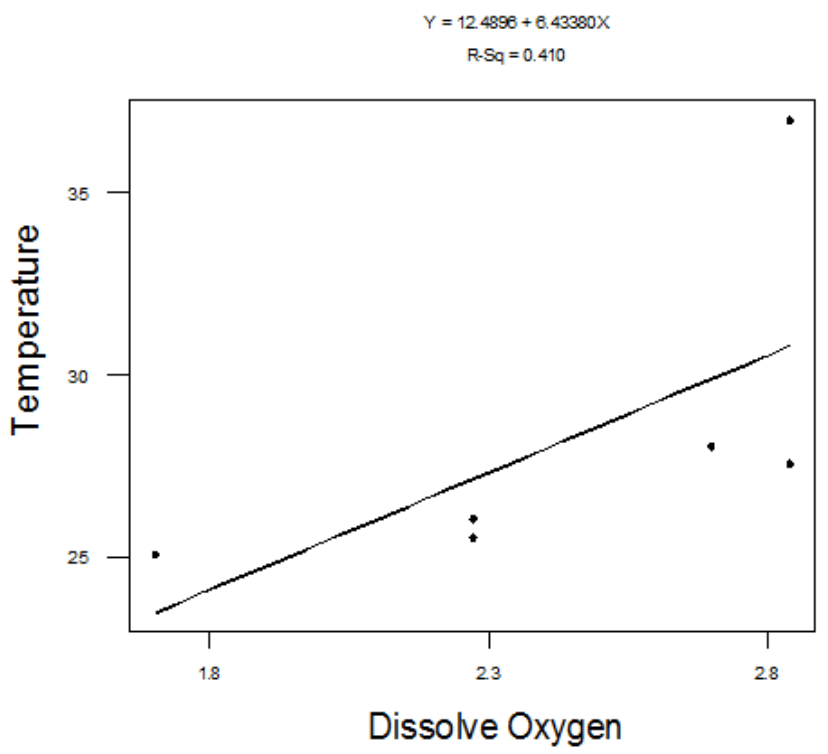

Figure 7: Relationship between temperature and salinity of seawater collected from Gwadar East Bay.
The variation in temperature in present study was also similar to the earlier observations made along the coast of Karachi (Qari and Siddiqui, [18]; Hussein and Samad, [19]). The present study result showed that temperature of surface seawater was high like air temperature. Sekar et al. [3] reported that surface seawater temperature is governed by atmospheric temperature. The present results of temperature and $\mathrm{pH}$ agree with the previous observation for the same locality made by Khan et al. [4]. The $\mathrm{pH}$ (7.5-8) of present work was similar to the values obtained by Sekar et al. [3] for the seawater of Thoothukudi coastal areas in the Gulf for the surface water of Madras, India; for Karachi harbour and Rizvi et al. [20] for Bakran Creek. Precipitation and evaporation are the two processes which affected the salinity concentration. The present study was conducted in the month of September. In Pakistan the period July-September is counted for rainy season and in rainy season salinity decreased due to large amount of fresh water discharge (Hussein et al. [21]. The present result showed high salinity concentration (39-41\% for surface seawater and $37-39 \%$ for deep water) indicated shallowness of water and the effluent discharged from the industries nearby [3]. Rabbani et al. [12] reported that Gwadar Bay is still has no proper drainage and sewerage system. All effluents and waste material dumped directly into the sea. Hussein et al. [21] described that variation of salinity in surface seawater and deep seawater were related with season. The present results of salinity almost agree with the previous work of Dass et al. [22] for India, Rizvi et al. [20] for Karachi harbour, Hussein and Samad [19] for Sandspit, Karachi and Qari and Siddiqui [18] for Nathia Gali, Karachi. Arabian seawater especially in the Northern part characterized by a relatively low content of dissolved oxygen. In present study low concentration of dissolved oxygen (1.7-2.84 mL $\mathrm{L}^{-1}$ ) may be due to the anthropogenic activities such as industrial wastes and sewage discharged causes eutrophication which is characterized by excessive algal growth due to the increased availability of one or more limiting growth factors needed for photosynthesis such as sunlight, carbon dioxide and nutrients [23]. In present investigation the seawater colour was greenish blue and odour was more or less stinky. Which is due to dead algal plants (phytoplankton and seaweeds), when they decomposed by bacterial action produced an aromatic gas Dimethyl Sufide (DMS). The 
oxidation of organic material, intense upwelling and high temperature of seawater also reduced the dissolved oxygen in seawater [24].

\section{Conclusion and Recommendation}

The present observation forms a baseline study in the area of Gwadar Bay. The present study shows that a number of industries like Gel mineral water plant, Al Makran Ice factory, Mir seafood companies, China Power Company and Desalination plant salt disposal affect the quality of sea water by direct discharge of effluents which are multi-component waste with multiple effects on water sediments and marine organisms. Apart from this land drainage, sewage and high temperature increased sedimentation rate and affect the marine ecosystem. Hence, it is necessary all effluents should be treated properly before released into the sea for the safety of marine environment.

\section{References}

1. Eswari A, Amala B, Poonguzhali TV. Studies on the physico chemical analyses of two different water bodies. Internat J Sci Env and Tech 2015;4:1377-1383.

2. Clara Jeyageetha J, Kumar SP. Study of physico-chemical parameters of sea water in Tuticorin Coastal area and assessing their Quality, Tamil Nadu, India. J Chem and Pharmaceut Res 2015;7:1298-1304.

3. Puthiya Sekar C, Poongothai S, Neelakantan MA. Impact of industrial pollution on the physicochemical characteristics of sea water in Thoothukudi coastal area. Rasayan J Chem 2009;2:912-919.

4. Khan MA, Shaukat SS, Saleem M. Diversity of Molluscan communities of Gwadar East Bay at Balochistan Coast. Proceeding of the seminar on Aquatic Biodiversity of Pakistan 1999;87-96.

5. Saleem M, Khan MA, Kazmi QB. Heavy metal distribution in the surface sediment of Gwadar East Bay (North West Arabian). Pak J Marine Sci 1999;8:99-105.

6. Nair SM, Balchand AN. Hydrochemical constituents in the Alleppey mud bank area, southwest coast of India. Ind J Marine Sci 1992;21:183-187.

7. Mitra A, Patra KC, Panigrahy RC. Seasonal variations of some hydrographic parameters in a tidal creek opening in to the Bay of Bengal. Mahasagar 1990;23:55-62.

8. De Sousa SN, Singbal SYS. Chemical oceanography of the Arabian Sea: part VI- Relationship between Nutrients and dissolved oxygen in the Central Basin. Ind J Marine Sci 1986;15:153-161.

9. Naqvi SWA, De Souza SN, Reddy CVG. Relationship between nutrients and dissolve oxygen with special reference to water masses on western Bay of Bengal. Ind J Marine Sci 1978;7:15-17.

10. Sen Gupta R, Fondekar SP, Sankaranarayanan VN, De Sousa SN. Chemical Oceanography of the Arabian Sea: Part 1- Hydrochemical and Hydrographical features of the Northern Basin. Ind J Marine Sci 1975;4:136-140.

11. Ganapati PN, La Fond EC, Bhavanarayana PV. On the vertical distribution of chemical constituents in the shelf waters off Waltair. In: Proceeding. Ind Academy of Sci 1956;64:68-72.

12. Rabbani MM, Atiq-ur-Rehman, Clrence EH. Mass mortality of fish caused by dinoflagellates bloom in Gwadar Bay South Western Pakistan. In Toxic marine plankton, proceedinga of the fourth international conference on Toxic Marine plankton. Sandstorm EGB, Edler L, Anderson DM (Eds). Elsevier 1989;209-214.

13. Memon GM, Ali SI. Survey of placer mineral deposite along the Makran coast Balochistann, Pakistan. 1995;98.

14. Martin DF. Marine chemistry 1: Marcel Dekker INC, New York. 1972;389.

15. Rodier J. Analysis of water, In: Environmental chemical analysis. Marr IL, Cresser MS (Eds). International textbook Company. Chapman and Hall New York, 1975;258.

16. Marr IL, Cresser MS. Environmental chemical analysis. International textbook Company. Chapman and Hall New York. 1983;258

17. La Fond EC. Oceanographic studies in the Bay of Bengal. In: Proceeding. Ind Academy of Sci 1957;66:1-46.

18. Qari R, Siddiqui SA. Variations of hydrographic conditions in seawater from Nathia Gali of Karachi coast. Pak J Marine Sci 2005;14:93-100.

19. Hussein SM, Samad M. Some physico-chemical parameters of backwater of Sandpit (Northern Arabian Sea, Pakistan coast. Pak J Zoology. 1995;27:191-194.

20. Rizvi SHN, Saleem M, Baquer J. Steel mill effluents: Influence on the Bakran Creek environment. In: Proceeding Marine Science of the Arabian Sea. Thompson MF, Tirmizi NM (Eds). American institutes of biological sciences. Washington 1988;549-569.

21. Hussein MM, Mahmood N, Bhouyain AM. some water quality characteristics of the Karnafully river estuary. Mahasagar 1988;21:183-188.

22. Dass SB, Kamat SY, Fernandes L, Reddy CVG. Seasonal changes in carrageenan and other biochemical constituents of Hypnea musciformis. Ind J Marine Sci 1980;9:134-136.

23. Schindler DW. Recent advances in the understanding and management of eutrophication. Limnol Oceanogr 2006; 51:356-363.

24. Rao IM, Satyanarayana D, Balasubrahmanian $T$, Subrahmanian AN. Chemical oceanographic studies of coastal waters off Madras. Ind J Marine Sci 1982;11:333-335. 